\title{
永久磁石による磁気吸着機構 を用いた進行波型全方向壁面移動ロボットの開発
}

\author{
呉 哲 英* · 澤 達 也* \\ 小川 曜 義*.中 村 太 郎* \\ Development of Traveling Wave Type Omni-directional Wall Climbing Robot \\ Using an Adhesion Device with Permanent Magnet \\ Tetsuhide Go*, Tatsuya OsawA*, \\ Teruyoshi Ogawa* and Taro Nakamura*

\begin{abstract}
We have developed the traveling wave type omni-directional mobile robot that imitates the snail locomotion mechanism. An advantage of this movement mechanism is that it enables stable motion because of a large contact area. We think that this stable motion is applicable to wall climbing. In this paper, we developed magnetic adhesion mechanism that can be switched adhesion and installed it in the robot. Furthermore, we confirmed the performance of this robot through experiments.
\end{abstract}

Key Words: climbing robot, omnidirectional-mobile robot, permanent magnet, magnetic adhesion, snail

\section{1. 緒言}

船舶やガスタンク, 発電所などの圧力容器の外壁は, 安全 性の面から，定期的に保守点検をする必要がある。こういっ た検査は高所での作業となるため，危険であったりコストや 時間がかかったりといった問題点がある。そのため壁面移動 能力をもったロボットによる作業の代行が求められている.

既存の研究として, 検査対象となる構造体は鋼などの強磁 性体でできていることから永久磁石を吸着機構としたロボッ トが多く開発されている1) 3). また，車輪と永久磁石を用い て全方向移動するロボットも開発されている ${ }^{4)}$. しかしそれ らのロボットは接地面積が小さいことに加えて, 吸着面から 得られる摩擦力が小さいため, 安定した移動が実現できない 問題がある。また同様の理由により，吸着力を確保するため の永久磁石が大型化し重量の増加や移動に必要なエネルギが 大きくなるといった問題がある.

一方, 著者らはカタッムリの移動機構に着目し, 水平面を 移動するための進行波型全方向移動ロボットの研究を行なっ てきた ${ }^{5), 6)}$. このロボットは接地面積が大きく, 安定した全 方向移動が可能である。 そこで本移動機構に, 磁石による吸

* 中央大学大学院理工学研究科 東京都文京区春日 1-13-27

* Graduate School of Science and Engineering, Chuo University, 1-13-27 Kasuga, Bunkyo-ku, Tokyo

(Received June 17, 2014)

(Revised November 28, 2014)
着機構を組み合わせることで, 上述のような強磁性体の壁面 での移動に応用できるのではないかと考えた.

本論文では, 永久磁石による磁気吸着機構を開発し, 吸着 力の算出および実験により測定を行なう。また，開発した磁 気吸着機構を応用した進行波型全方向壁面移動ロボットを開 発し, 実験により全方向移動性, 旋回性を確認する.

\section{2. 進行波型全方向壁面移動ロボット}

\section{1 ロボットの概要}

進行波型全方向壁面移動ロボットの全体図を Fig. 1 に示 す．また仕様を Table 1 に示す．本ロボットは伸縮する 8 個 のユニットを，モータを介して円環状に接続した構造となっ

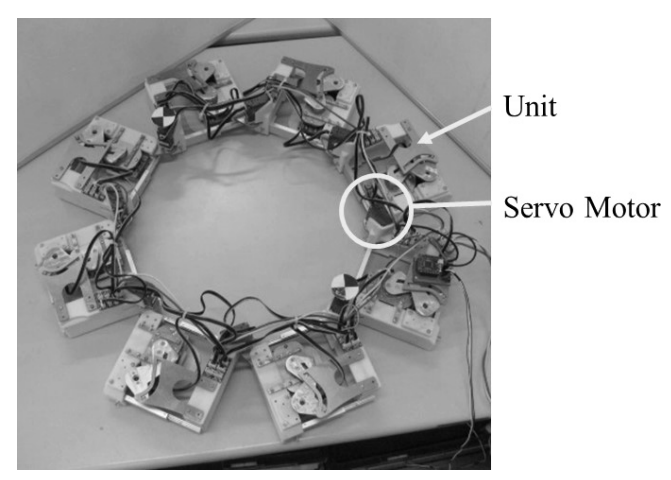

Fig. 1 Traveling-wave-type omni-directional wall climbing robot 
ている．また，それぞれのユニットに永久磁石を用いた磁気 吸着機構を搭載している。

\section{2 ユニットの構造}

ユニットの構造を Fig. 2 に示す。また Table 2 にユニッ トの仕様を示す。ユニットにはユニット回転用モータと伸縮一 磁石回転用モータの 2 つのサーボモータが取り付けられて いる.

ユニット回転用モータはアームに直結しており，ユニット 間の角度を制御することが可能である.

伸縮一磁石回転用モー夕にはカムの原動節が取り付けられて おり，ユニットの伸縮運動と磁石の回転の 2 つの動作を，カ ム機構を用いて 1 つのサーボモータで行なう.

Table 1 Specifications of robot

\begin{tabular}{|c|r|}
\hline Maximum Diameter[mm] & 686 \\
\hline Height $[\mathrm{mm}]$ & 85 \\
\hline Weight $[\mathrm{mm}]$ & 7.2 \\
\hline
\end{tabular}

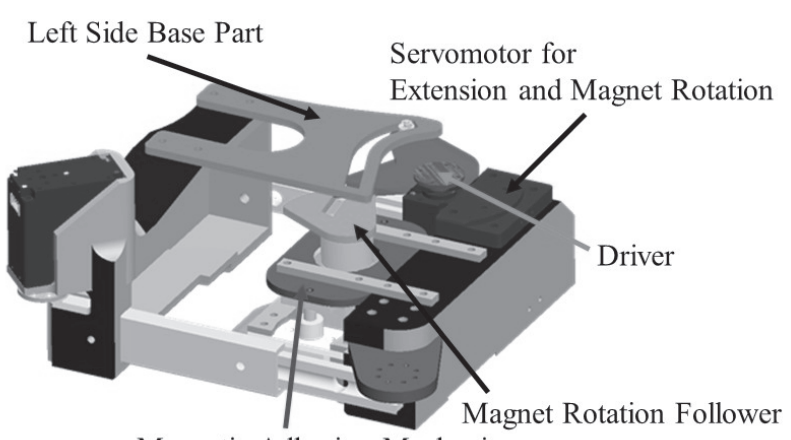

Magnetic Adhesion Mechanism

(a) Upper Side

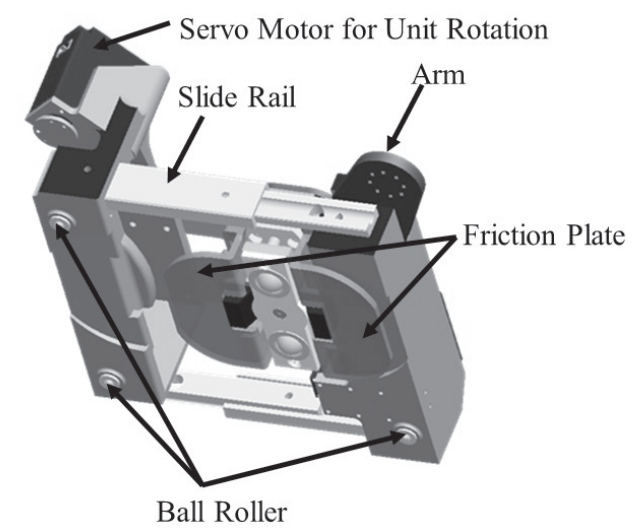

(b) Under Side

Fig. 2 Mechanism of unit

Table 2 Specification of unit

\begin{tabular}{|c|c|c|}
\hline Depth $[\mathrm{mm}]$ & \multicolumn{2}{|c|}{155} \\
\hline Width $[\mathrm{mm}]$ & Contracting & 105 \\
\hline Height $[\mathrm{mm}]$ & Extending & 150 \\
\hline Weight $[\mathrm{g}]$ & & 900 \\
\hline
\end{tabular}

\section{3. 磁気吸着機構}

\section{1 磁気吸着機構の構造}

壁面に吸着するための磁気吸着機構の構造を Fig. 3 に示 す。中心の筒状の永久磁石を囲むように吸着側ヨークとロー ラ側ヨークがそれぞれ 2 つ一組で向かい合って配置されてお り, 中心の磁石は回転できるようになっている。吸着側ヨー クはシャフトとリニアブシュを通して固定されており，上下 運動が可能である。 また，ローラ側ヨークの下側には磁性体 のローラが埋め込まれている。

中心の磁石が 90 度回転することで Fig. 4 のように磁極の 方向を吸着側ヨーク，ローラ側ヨークと変えることができる. これにより，吸着面と成す磁気回路を 2 つのパターンに切り 替えることができる.

Fig. 4(a)の磁気回路パターン 1 の状態では磁石の磁極は吸 着用ヨークの方向に回転しており, 吸着用ヨークは吸着面と磁 気回路を形成しようとする。よって，吸着用ヨークは下図の 矢印で示すように吸着面に引き寄せられ大きな吸着力を発生 する. また, Fig. 2(b)のように, 磁気吸着機構にはゴムシー 卜を貼り付けた摩擦板を取り付けている。パターン 1 のとき は吸着用ヨークと一緒に摩擦板が下りてくるので, 大きな接

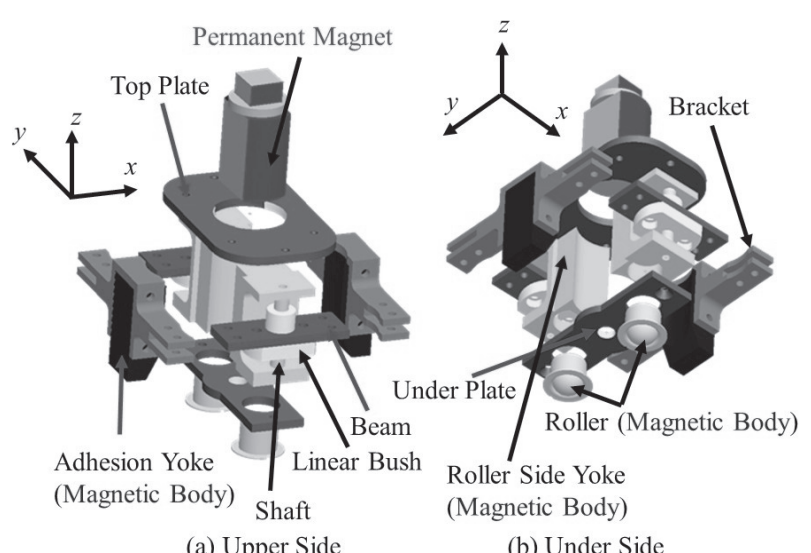

$\begin{array}{ll}\text { (a) Upper Side } & \text { (b) Under Side }\end{array}$

Fig. 3 Magnetic adhesion mechanism
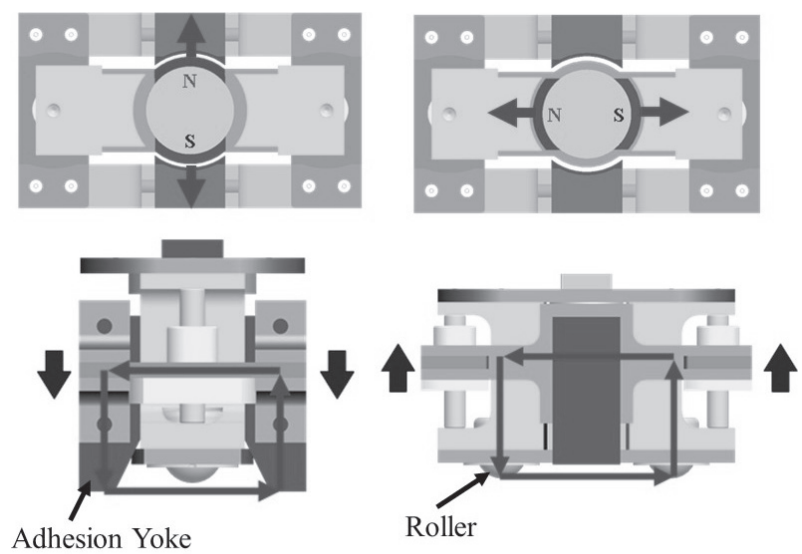

(a) Pattern1

(b) Pattern2

Fig. 4 Patterns of magnetic circuit 


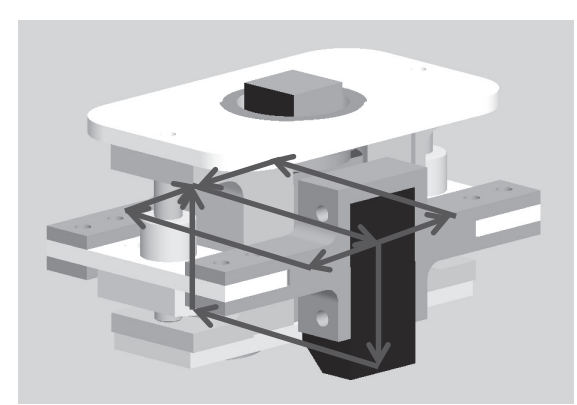

Fig. 5 Modeled magnetic circuit

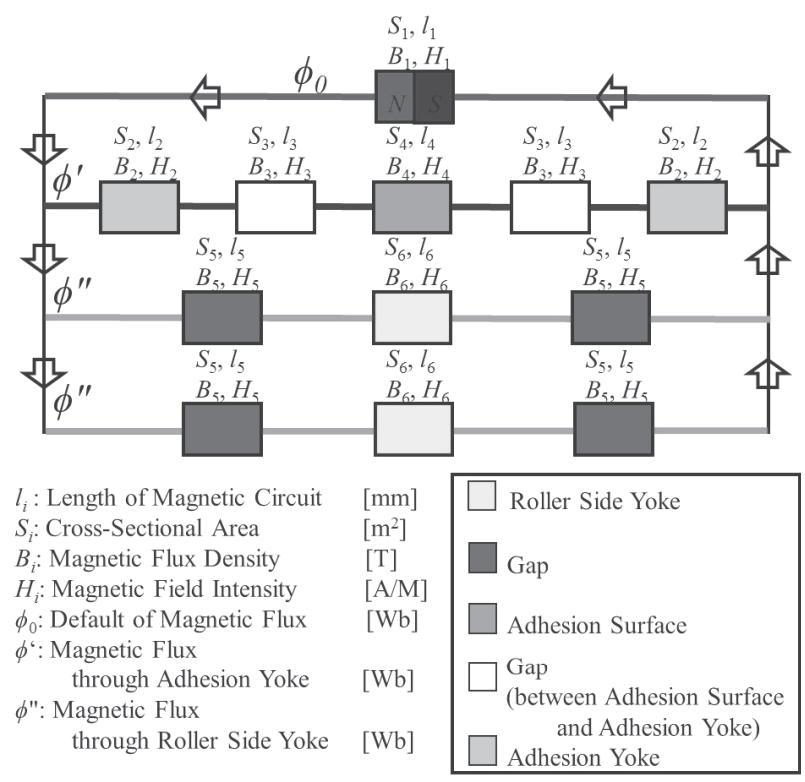

Fig. 6 Magnetic circuit model

地面積を確保し，吸着面との間に大きな摩擦力を発生できる.

Fig. 4(b) の磁気回路パターン 2 の状態では磁石の磁極は ローラ側ヨークの方向に回転しており，ローラを介して磁気 回路が形成される。そのため吸着力は発生するが摩擦は小さ く, 容易に磁気吸着機構を動かすことができる. また, 吸着 用ヨークは磁石の漏れ磁束によって磁石の真横に位置しよう と移動するため, 矢印の方向に自然と移動し, 吸着面から離 れる。よって, 磁石の回転のみによって吸着用ヨークは上下 運動を行なうことができる.

このように回路を切り替えることで吸着力を常に発生しつ つ, 自由に動ける状態と吸着面に固定される状態を切り替え ることができる。

\section{2 磁気吸着機構の吸着力の算出}

磁気吸着機構がどの程度吸着力を発生させることができる かを理論的に確認する。磁気吸着機構吸着時における磁気回 路を Fig. 5 のように示す。吸着用ヨークと吸着面を介して形 成される磁気回路と, 磁束の漏れとしてローラ側ヨークを介 して短絡してしまう磁気回路との並列回路によってモデル化 を行なう。モデル化した磁気回路モデルを Fig. 6 に示す.ま た，磁気吸着機構の各パラメー夕を Table 3 に示す.

また，ヨークの材料は SS400 を使用しているが，磁気飽和
Table 3 Parameters of magnetic circuit model

\begin{tabular}{|r|r||l|r|}
\hline$S_{1}\left[\mathrm{~mm}^{2}\right]$ & 150 & $L_{1}[\mathrm{~mm}]$ & 15 \\
\hline$S_{2}\left[\mathrm{~mm}^{2}\right]$ & 120 & $L_{2}[\mathrm{~mm}]$ & 16 \\
\hline$S_{3}\left[\mathrm{~mm}^{2}\right]$ & 120 & $L_{3}[\mathrm{~mm}]$ & 0 \\
\hline$S_{5}\left[\mathrm{~mm}^{2}\right]$ & 280 & $L_{5}[\mathrm{~mm}]$ & 5 \\
\hline$S_{6}\left[\mathrm{~mm}^{2}\right]$ & 280 & $L_{6}[\mathrm{~mm}]$ & 16.5 \\
\hline
\end{tabular}

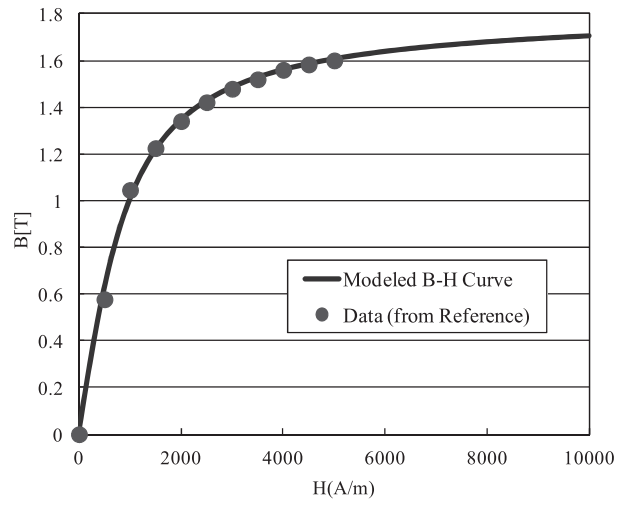

Fig. 7 Modeled B-H curve

による磁化特性の非線形性が無視できない，そこで SS400の 磁化特性を非線形的にモデル化する，モデル式として，磁化 特性の非線形性を考慮するためによく用いられる (1) 式を用 (る ${ }^{7), 8)}$.

$$
B=\frac{\pi}{2} B_{\text {sat }} \operatorname{atan}\left(\frac{\pi H}{2 a}\right)+\mu_{0} H
$$

ここで $B$ は磁束密度， $\mu_{0}$ が真空の透磁率である. (1) 式にお ける係数 $B_{\text {sat }}, a$ をS 400 の磁化特性のデー夕を用いて最小 二乗法によって求めると $(2),(3)$ 式のようになる.

$$
\begin{aligned}
B_{\text {sat }} & =1.785 \\
a & =1295
\end{aligned}
$$

Fig. 7 に磁化特性のデータ ${ }^{9)}$ とモデル化した磁化曲線の比較 を示す．この図より，モデル化した磁化特性が資料のデー夕 とよく一致していることがわかる。なお，ギャップにおける 磁化特性は, 真空の透磁率 $\mu_{0}$ を用いて (4) 式のように線形 的に扱う.

$$
B=\mu_{0} H
$$

また，今回使用するネオジム磁石の磁化特性も一般的に非線 形性は無視できるので (5) 式のように表わされる.

$$
B=\frac{B_{p}}{H_{c}} H+B_{p}
$$

ここで, 今回使用するネオジム磁石の仕様は残留磁束密度： $B_{p}=1.2 \mathrm{~T}$, 保持力 : $H_{c}=900 \mathrm{kA} / \mathrm{m}$ となっている.

また, 吸着面に関しては広い面積をもつため, 磁気回路は直 線的には形成されない。そのため, 磁化特性を断面積と長さ のみで非線形的にモデル化すると磁気抵抗が大きくなり，実 際の吸着力よりも小さい值が算出されてしまう。そこで, 磁 気飽和を起こす支配的な要因はヨークであるので，吸着面に 
関しては磁気飽和を考慮せずに, 磁化特性は (6) 式のように 扱う。ここで $\mu_{1}$ は一般的な強磁性体の透磁率 $\mu_{1}=1000 \mu_{0}$ である。これを用いて吸着面の磁化特性をモデル化する.

$$
B=\mu_{1} H
$$

ヨークの非線形性を考慮するために, 繰り返し計算によって吸 着力を算出する．計算手法は以下の流れによって行なわれる. Step1：磁石から出る磁束の初期值 $\phi_{0}$ を適当に設定する。す ると以下の 2 式が成り立ち $B_{1}, H_{1}$ を求めることができる.

$$
\begin{aligned}
B_{1} & =\frac{\phi_{0}}{S_{1}} \\
H_{1} & =\frac{H_{c}}{B_{p}}\left(B_{1}-B_{p}\right)
\end{aligned}
$$

Step2：キルヒホッフ第 2 法則より以下の 2 式が成り立つ.

$$
\begin{aligned}
& H_{1} l_{1}+2 H_{2} l_{2}+2 H_{3} l_{3}+H_{4} l_{4}=0 \\
& H_{1} l_{1}+2 H_{5} l_{5}+2 H_{6} l_{6}=0
\end{aligned}
$$

また，直列回路において磁束の漏れがないと仮定すれば以 下の 2 式が成り立つ.

$$
\begin{aligned}
& \phi^{\prime}=B_{2} S_{2}=B_{3} S_{3}=B_{4} S_{4} \\
& \phi^{\prime \prime}=B_{5} S_{5}=B_{6} S_{6}
\end{aligned}
$$

そして，(4)，(5)，(11)，(12) 式を用いて (9)，(10) 式を満 たすように $\phi^{\prime} ， \phi^{\prime \prime}$ をニートン法により決定する.

Step3:磁気回路モデル外に磁束が漏れないと仮定すれば (13) 式が成り立つ。

$$
\phi_{0}=\phi^{\prime}+2 \phi^{\prime \prime}
$$

しかし，(12) 式の右辺と左辺はStep1 で $\phi_{0}$ を適当に設定 したために一致しない。そこで，つぎに探索する $\phi_{1}$ を(14) 式のように決定する.

$$
\phi_{1}=\phi_{0}+K\left\{\left(\phi^{\prime}+2 \phi^{\prime \prime}\right)-\phi_{0}\right\}
$$

ここで， $K$ は数值計算を発散させないようにするための縮小 因子である.今回は $K=0.05$ で計算を行なっている。これ らの Step1〜Step3 の操作を繰り返し行ない, (12) 式を満た すまで計算を行なうことで，吸着用ヨークと吸着面との間の ギャップを通過する磁束密度 $B_{3}$ を求めることができる。こ の磁束密度 $B_{3}$ より, 吸着用ヨークと吸着面に働く吸着力は (15) 式のように求まる.

$$
F=\frac{1}{\mu_{0}} B_{3}^{2} S_{3}
$$

\section{3 吸着力の理論値と実験値}

厚さ $2 \mathrm{~mm}$ で比透磁率が 1000 の板に吸着した際のギャッ プの長さと吸引力 $F$ の関係の理論值と実験值を Fig. 8 示す. ギャップが $0 \mathrm{~mm}$ のときの吸着力の理論值は $187 \mathrm{~N}$ であっ たが実験結果は $120 \mathrm{~N}$ であった．Fig. 8 より全体的に理論值 と実験值は傾向が似ていることがわかる．理論值に対して実 験值は低い值となっているのは，磁束の漏れによって吸着力

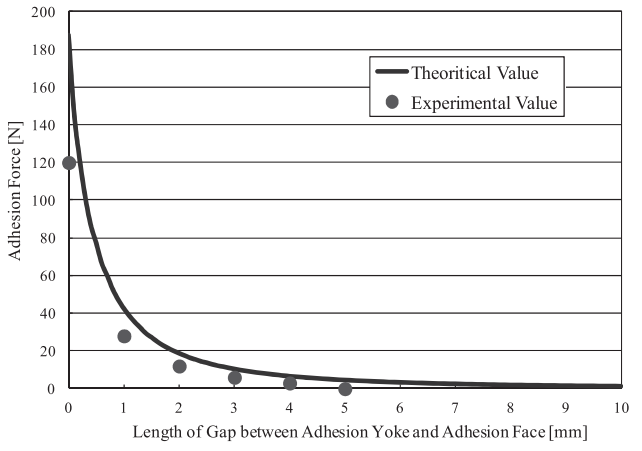

Fig. 8 Relationship between gap length and adhesion force

が低下してしまうためだと考える。今後, 磁気吸着機構の設 計を改良する際には吸着力に係数をかけることで設計の段階 で吸着力を予想することは可能であると考える，また，磁気 吸着機構の可動部分の重さは約 $180 \mathrm{~g}$ であり, 理論上ギャッ プの距離が $5 \mathrm{~mm}$ までならば吸着ヨークの上下運動が可能と 考えたが実際には $4 \mathrm{~mm}$ の上下運動となった。

ローラ側の吸着力の実験結果は $20 \mathrm{~N}$ であった。この吸着 力は 1 ユニットの重さ約 $900 \mathrm{~g}$ を支えるのに十分な吸着力で ある。

最後に, 摩擦板を取り付けた際の磁気吸着機構の並進静止 摩擦力は $65 \mathrm{~N}$ であった。作製するロボットは移動時に最大で 4 つのユニットが固定されない状態になる。したがって 1 ユ ニットで 2 ユニット分の重量を支える必要があるがユニット の重さに対して約 7 倍の摩擦力が発生しているので, ロボッ トが落下することはない.

\section{4. カムによる伸縮一磁石回転機構}

伸縮一磁石回転用モータによってユニットが動作するよう すを Fig. 9 に示す．まず Fig. 9(a) の状態では磁石は吸着用 ヨークの方向に回転しておりユニットが伸長し固定されてい

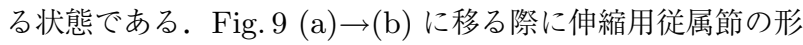
状は原動節収縮側の軌道と一致しているために伸縮運動は行 なわれない。一方，磁石回転用のカムはかみ合い，磁石を 90 度回転させ, Fig. 4(b) の磁気回路パターンになるためユニッ 卜を容易に動かせる状態になる．Fig. 9(b) のとき原動節収縮 側の軌道と伸縮用従属節の形状が一致しなくなる境目であり, 磁石回転用のカ厶同士がかみ合わなくなる境目となっている.

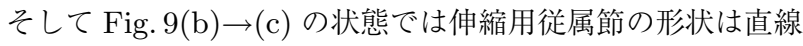
形状になっており，収縮運動を行なう。また, Fig. 9(b)のロー ラ側の磁気回路になっているため摩擦が少なく，ユニットを 容易に移動させることができる。

\section{5. ロボットの移動制御手法}

\section{1 ロボット全体形状のモデル}

まず初めに，ロボット全体の形状をモデル化する，モデル 化したロボット形状を Fig. 10 に示す。本ロボットはユニッ トの連結部分をアクティブジョイントとし，ユニットを伸縮 


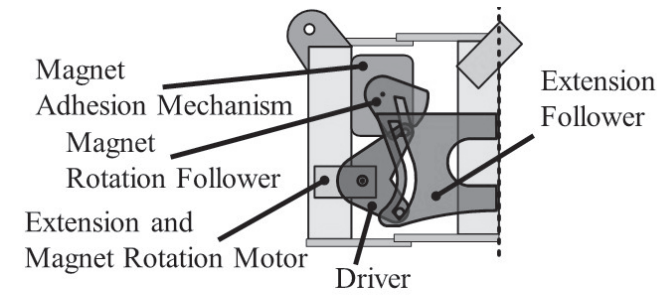

(a) Extending with Adhesion

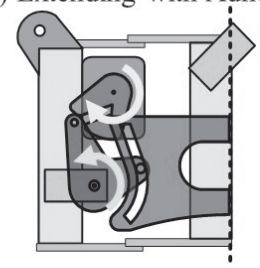

(b) Extending without Adhesion

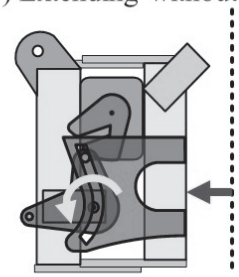

(c) Contracting without Adhesion

Fig. 9 Motion of unit

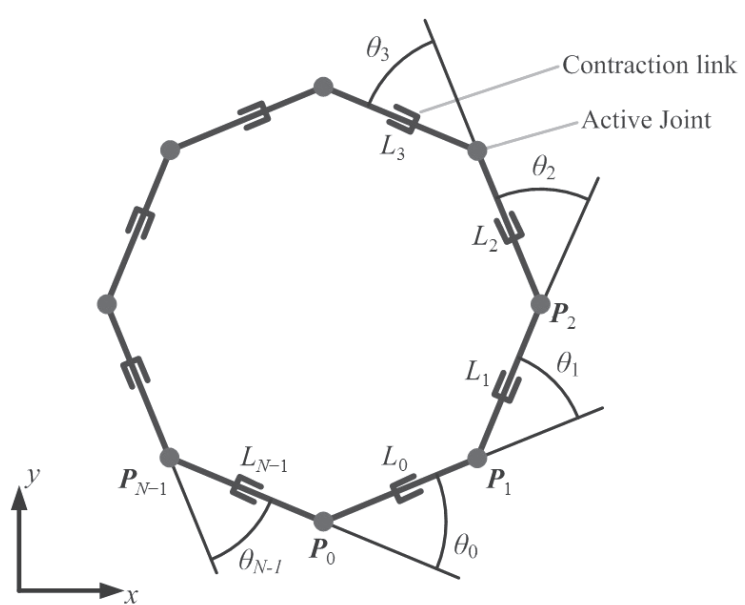

Fig. 10 Model of robot

可能リンクとした 8 角形の形状として表わすことができる. つぎに，モデル化したロボット形状のモデル式を求める. まず，Fig. 10 のようにリンクの長さを $L$, 各リンクのなす角 を $\theta$, 連結部の座標を $\boldsymbol{P}_{i}(x, y)$, ユニットの数を $N$ とする. そして, あるリンク $L_{0}$ から運動学を解くと, 連結部の座標 $\boldsymbol{P}_{i}$ は (16) 式で表わされる. ただし， $\boldsymbol{P}_{0}, \boldsymbol{P}_{1}$ は既知とする.

$$
\boldsymbol{P}_{i}=\left[\begin{array}{l}
x_{i} \\
y_{i}
\end{array}\right]=\left[\begin{array}{r}
x_{i-1}+L_{i-1} \cos \left(\theta_{\text {def }}+\sum_{i=1}^{N-1} \theta_{i}\right) \\
y_{i-1}+L_{i-1} \sin \left(\theta_{\text {def }}+\sum_{i=1}^{N-1} \theta_{i}\right)
\end{array}\right]
$$

$$
\theta_{\text {def }}=\arctan \left\{\left(y_{1}-y_{0}\right) /\left(x_{1}-x_{0}\right)\right\}
$$

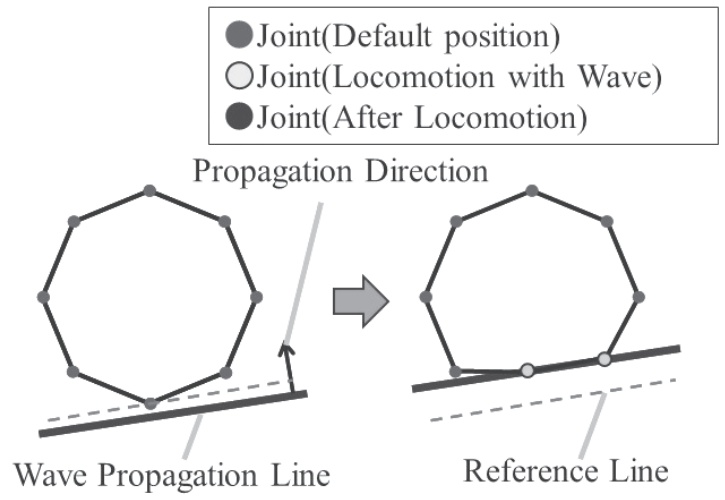

(a) Default Position

(b) State 1
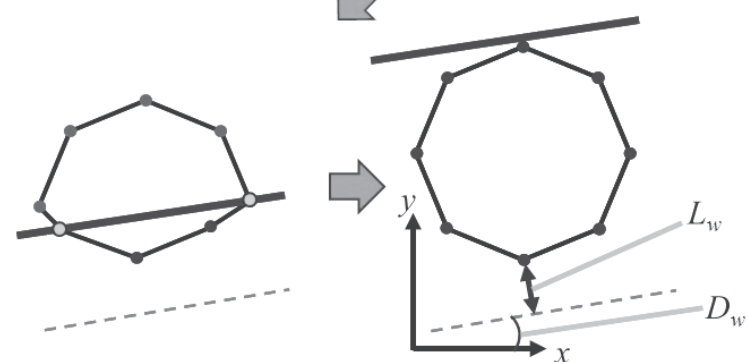

(c) State2

(d) End State

Fig. 11 Omni-directional

$i=2,3, \cdots, N-1$

\section{2 全方向移動手法}

モデル化したロボットの形状を用いて全方向に移動するた めのモーション生成を行なう。ここで, 全方向移動手法の概 要を Fig. 11 に示す.

まず，Fig. 11 のようにワールド座標系となす進行角度を $D_{w}$, 速さを $V_{w}$, 波長を $L_{w}$ とする波動伝播線を定義する. そして，モデル化したロボット形状の平面上に波動伝播線を 伝播させる.Fig. 11 (a)のように, Joint と波動伝播線がま だ重なっていないとき, Joint の座標 $\boldsymbol{P}_{o i}$ は (16) 式を用いて (17) 式のように表わされる.

$$
\boldsymbol{P}_{o i}=\boldsymbol{P}_{i}
$$

つぎに, Fig. 11 (b) のように Joint と波動伝播線が重なっ たら，波動伝播線と重なったJoint を，波長の值だけ波動伝播 線と一緒に移動させる.そして, 波動伝播線と重なった Joint の座標 $\boldsymbol{P}_{o i}$ は (16) 式を用いて (18) 式のように表わされる. ここで，あるJoint と波動伝播線が重なった時間を $t_{o}$, 現在 の時間を $t$ とする.

$$
\begin{aligned}
\boldsymbol{P}_{o i} & =\boldsymbol{P}_{i}+\boldsymbol{M}_{i} \\
\boldsymbol{M}_{i} & =\left[\begin{array}{l}
V_{w} \cos \left(D_{w}\right) \times\left(t_{i}-t_{o i}\right) \\
V_{w} \sin \left(D_{w}\right) \times\left(t_{i}-t_{o i}\right)
\end{array}\right]
\end{aligned}
$$

さらに, Fig. 11 (c) のように, Joint は波長の值だ移動す ると，その場で停止する。この停止した Joint の座標は (16) 式を用いて (19) 式のように表わされる. 最後に, Fig. 11 (d) 
のように全部の Joint が移動を終了すれば，ロボットの 1 つ の移動動作は完了である。この動作を繰り返すことにより， 任意の方向に移動可能になる。

$$
\boldsymbol{P}_{o i}=\boldsymbol{P}_{i}+\left[\begin{array}{c}
L_{w} \cos \left(D_{w}\right) \\
L_{w} \sin \left(D_{w}\right)
\end{array}\right]
$$

この手法によりロボットの形状を制御することができる.

\section{3 旋回移動手法}

モデル化したロボットの形状を用いて旋回動作をするため のモーション生成を行なう。まずはじめに，旋回を行なうた めの予備動作として Fig. 12(a)のように対角線上にある $2 つ$
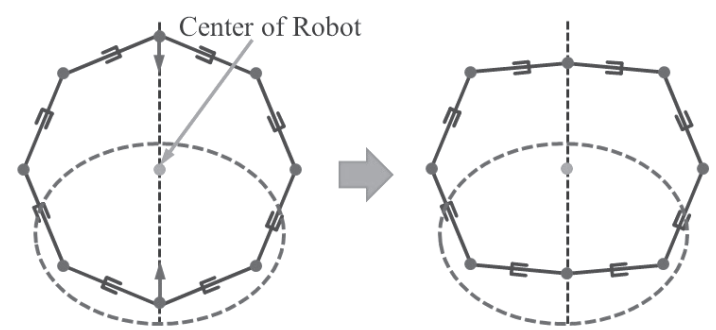

(a)Preliminary Motion

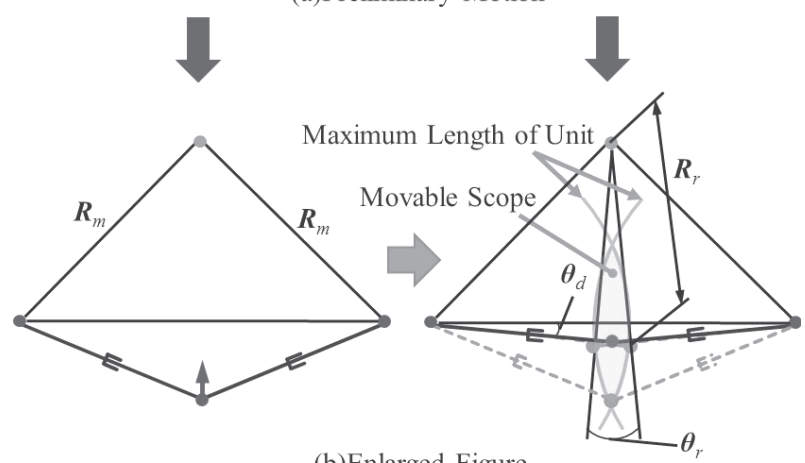

(b)Enlarged Figure

Fig. 12 Preliminary motion for turning locomotion method

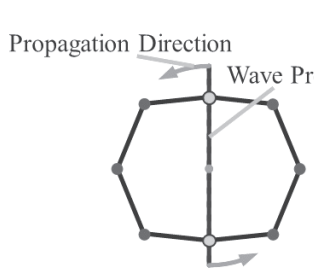

(a) Default Position

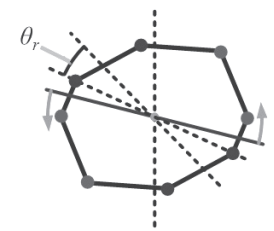

(c) State 2

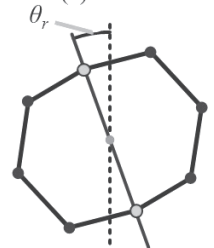

(e) End State

Fig. 13 Turning locomotion method
のジョイントをロボット中心に向かって移動させる。すると， Fig. 12 (b) の拡大図のように移動したジョイントはロボット 中心を軸に $\theta_{r}$ だけ旋回方向に可動範囲が生まれる.

ここで, 内側に移動したジョイントの半径 $R_{r}$ と, 旋回方 向の可動範囲 $\theta_{r}$ は以下の式で表わされる。なお，リンクの最 大長さを $L_{\max }$, 移動前のジョイントの半径を $R_{m}$ とする.

$$
\begin{aligned}
\theta_{r}=2 \tan ^{-1} & \left(\frac{L_{\max } \cos \theta_{d}-\frac{1}{\sqrt{2}} R_{m}}{\frac{1}{\sqrt{2}} R_{m}+L_{\max } \sin \theta_{d}}\right) \\
R_{r}= & \left\{\left(\frac{1}{\sqrt{2}} R_{m}+L_{\max } \sin \theta_{d}\right)^{2}\right. \\
+ & \left.\left(L_{\max } \cos \theta_{d}-\frac{1}{\sqrt{2}} R_{m}\right)^{2}\right\}^{\frac{1}{2}}
\end{aligned}
$$

つぎに旋回手法の概要を Fig. 13 に示す。まず角速度を $\omega_{w}$, 波長角度を $\theta_{r}$ とする波動伝播線を定義する。Fig. 12 のよう に予備動作を行なった後，Fig. 13 (a) のようにロボット中心 を軸に，移動したジョイントの対角線上を初期位置として， 波動伝播線を回転させる。そして波動伝播線と重なったジョ イントを移動させる。まず予備動作を行なったジョイントを， 旋回角度の半分である $\theta_{r} / 2$ だけ波動伝播線と共に移動させ る.それ以外のジョイントは旋回角度 $\theta_{r}$ だけ移動させ，最後 に予備動作を行なったジョイントを残りの角度 $\theta_{r} / 2$ だけ移 動させる. 波動伝播線を $\pi+\theta_{r}$ だけ回転させたら波動伝播線 を停止する。この動作を繰り返し行なうことでロボットの姿 勢を任意の姿勢に制御することができる.

\section{6. 走行実験}

\section{1 全方向移動実験}

吸着面の傾斜が 0 度 (水平面), 90 度 (壁面), 180 度 (天井) の場合において，全方向移動が可能かどうか走行実験を行な う。この実験ではフィードフォワードのみによりロボットを 制御する。移動方向は 0 度から 180 度まで 10 度ずつ行ない, 設定値どおりにロボットが走行できるか確認する。一度の移 動量を $40 \mathrm{~mm}$ とし 3 回分移動させる。ロボットの移動軌跡

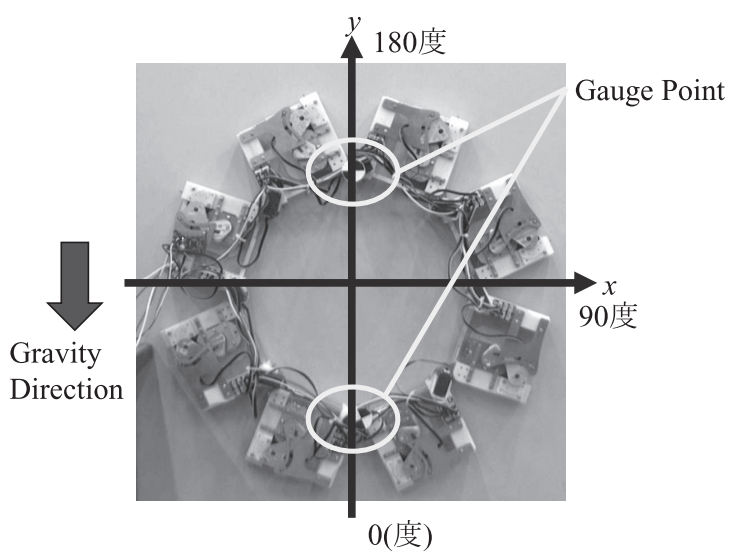

Fig. 14 Condition for locomotion experiment 


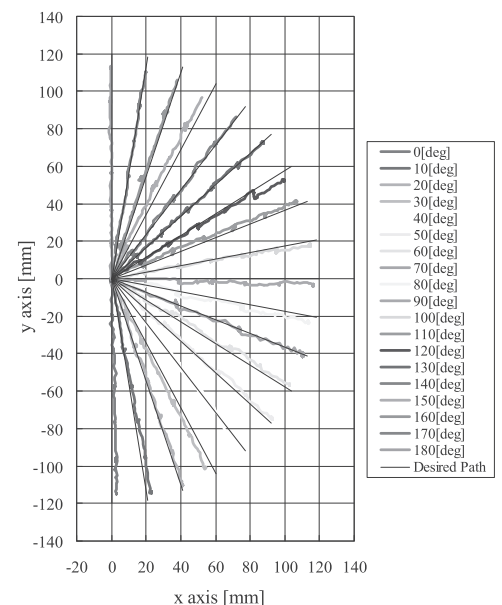

(a) $0\left[^{\circ}\right]$

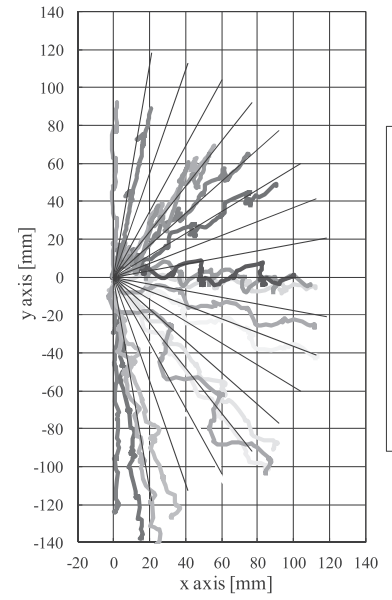

(b) $90\left[^{\circ}\right]$

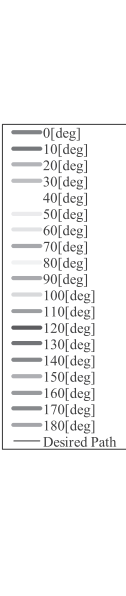

$\mathrm{x}$ Axis $[\mathrm{mm}]$

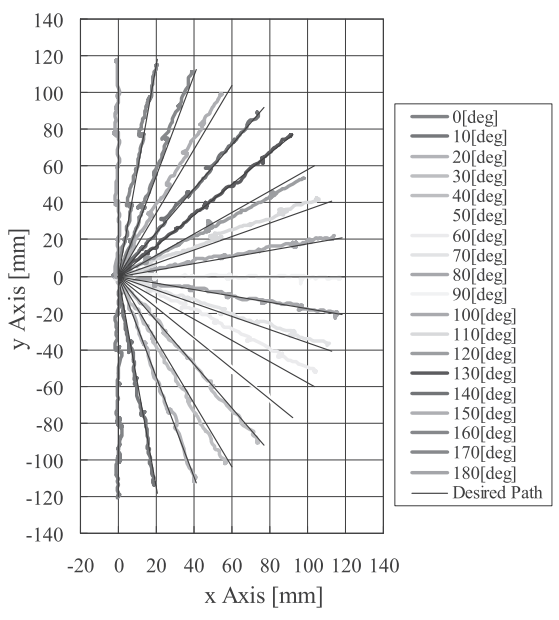

(c) $180\left[^{\circ}\right]$

Fig. 15 Result of omnidirectional locomotion experiment

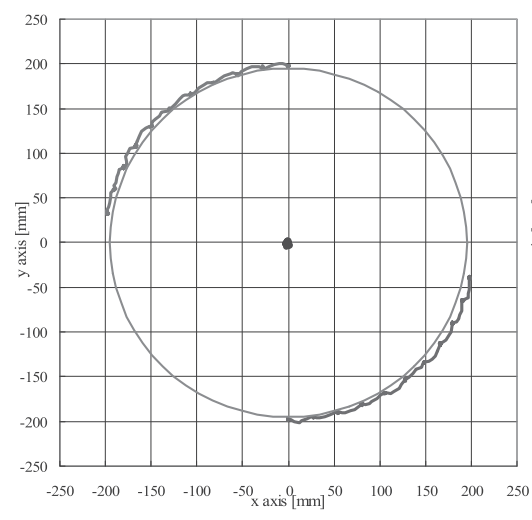

(a) $0\left[^{\circ}\right]$

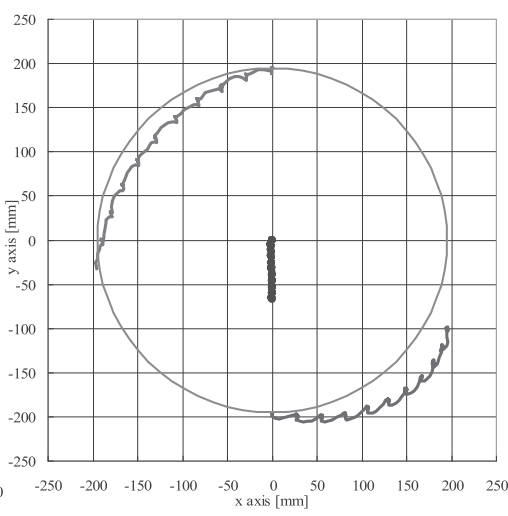

(b) $90\left[^{\circ}\right]$

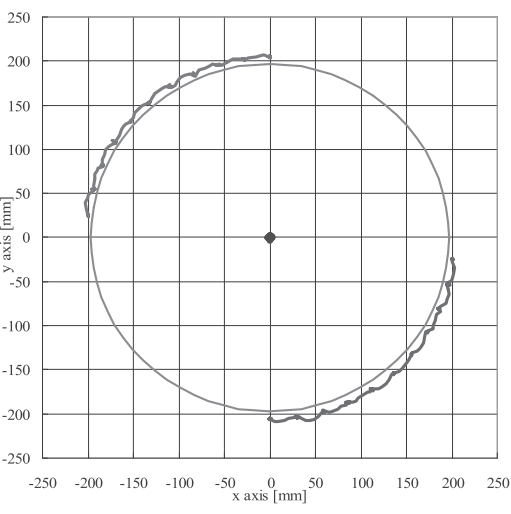

(c) $180\left[^{\circ}\right]$

Fig. 16 Result of turning locomotion experiment

の計測は nac 社の movias を用いて動画解析を行なった。動 画解析に用いた標点は Fig. 14 に示すようにユニット連結部 の 2 点を取りその中点を移動軌跡として評価する。

壁面の傾斜を変えて全方向移動実験を行なった結果を Fig. 15 に示す. Fig. 15(a) より水平面移動時には移動方向, 移動量共に目標どおり移動できていることがわかる。一方, Fig. 15(b) のように壁面を横方向に移動する場合，目標軌道 からずれてしまっていることがわかる，また，重力に逆らっ て上昇する際には移動量が目標よりも小さくなっていること がわかる。これは重力によりモー夕に大きな負荷がかかり， 指令值どおりにモータが回転しなかったためであると考える. Fig. 15(c) を見てみると水平面を移動しているのとほぼ変わ らない移動軌跡になっていることがわかる．今回の実験では 19 方向の実験を行なっているが, 実験を行なっている最中に ロボットが落下してしまうこともなく, 安定して移動できる ことを確認した。これは Fig. 4(b) に示す磁気回路パターン によって，移動しているユニットにおいてもそのユニット自 身が自重を支え，固定しているユニットに負荷を与えないた めであり, 本磁気吸着機構の有用性を確認することができた.
壁面においては重力の影響を受け移動経路に誤差が生じた ものの，どの傾斜においてもさまざまな方向に移動すること ができることが確認できた.

\section{2 旋回実験}

吸着面の傾斜が 0 度, 90 度, 180 度の場合において, 旋回 移動が可能かどうか走行実験を行なう。旋回は 9 度ずつ 10 回行ないロボットを 90 度回転させる。実験環境は 6.1 節と 同じとし，動画解析に用いた標点は Fig. 14 に示すようにロ ボットの対角線上にあるユニット連結部の 2 点を取り移動軌 跡を評価する。

実験結果を Fig. 16 に示す。なお，実験結果のグラフには それぞれの標点の軌跡に加えて，その中点の軌跡をロボット の中心座標としてロボット全体がどのように移動しているか も表示している.

実験結果を見てみると, 傾斜面の角度が 0 度と 180 度の場 合は標点が目標の移動軌跡に沿って正確に移動していること がわかる．また，ロボットの中心座標もほとんど移動してお らずその場で旋回できていることがわかる.

傾斜面の角度が 90 度の場合は旋回できてはいるものの, 口 
ボット全体として重力方向に約 $66 \mathrm{~mm}$ 移動している.これ は重力の影響を受けてモータが指令值どおりに回転していな いためだと考える．壁面においては重力の影響を受け重力方 向に移動したものの, どの傾斜面の角度においても, 旋回が 可能でありロボットの姿勢を制御できることが確認できた.

\section{7. をと め}

ロボットが壁面移動に適応するための磁気吸着機構を開発 し, 吸着力の算出を行なった.また, 吸着機構が設計どおり に動作することを確認した. さらに，ユニットの伸縮と磁石 の切り替えを行なえるカム機構を開発し, これを用いて磁気 吸着機構をロボットに適用した。作製したロボットを用いて 床面，壁面，天井において全方向移動および旋回動作を行な い，壁面移動時には重力による影響を受けたものの，どの面 においても脱落することなく移動できることを確認した。こ れは, 広い接地面積での移動と, 吸着力を発生しつつ移動と 固定を切り替えられる磁気吸着機構によって実現できたと考 える.

\section{8. 今後の展望}

外界センサによるフィードバック制御やユニットの剛性の 向上などにより，ロボットの移動精度の向上を図る，加えて， 重力の影響を考慮して指令角度に補正值を加えて, 実質的に 目標角度での走行を実現できるかどうかも検討する。また， 今回開発した進行波型全方向壁面移動ロボットは，ユニット の連結部分の機構が 1 自由度しかもたない.ガスタンクや船 の壁面は曲面のため, 曲面でも走行できるようにユニット連 結部分の設計改良を行なう.

\section{参 考 文 献}

1) W. Fischer, F. Tache and R. Siegwart: Inspection System for Very Thin and Fragile Surfaces, Based on a Pair of Wall Climbing Robots with Magnetic Wheels, Proc. of the 2007 IEEE/RSJ International Conference on Intelligent Robots and Systems, 1216/1221 (2007)

2) W. Shen, J. Gu and Y. Hen: Proposed Wall Climbing Robot with Permanent Magnetic Tracks for Inspecting Oil Tanks, Proc. of the 2005 IEEE International Conference on Mechatronics and Automation, 2072/2077 (2005)

3) L.P. Kalra, J. Gu and M. Meng: A Wall Climbing Robot for Oil Tank Inspection, Proc. of the 2006 IEEE International Conference on Robotics and Biomimetics, 1523/1528 (2006)

4）鶴，広瀬：ホロノミック全方向移動性を有する磁気吸着全方向 移動ロボットVmax III の開発, 日本ロボット学会誌, 30-6, 639/647 (2012)

5) K. Satoh and T. Nakamura: Development of an omnidirectional mobile robot based on snail locomotion, Proceedings of 7th International Conference on Climbing and Walking Robots and the Support Technologies for Mobile Machines, 144/152 (2007)

6）たとえば小川, 大澤, 中村, 大隈：進行波型全方向移動ロボッ トの変形とオドメトリを利用した省スペース移動計画，第 18 回ロボティクスシンポジア予稿集，419/424 (2013)
7) C. Perez-Rojas: Fitting saturation and hysteresis via arctangent functions, IEEE Power Engineering Review, 20-1, $55 / 57(2000)$

8）山川, 大川, 宮本 : 永久磁石磁気回路の設計と応用, 総合電子 出版 (1979)

9）電気学会マグネティックス技術委員会編：磁気工学の基礎と応 用, コロナ社 (1999)

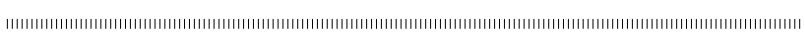

$$
\text { [著 者 紹 介] }
$$

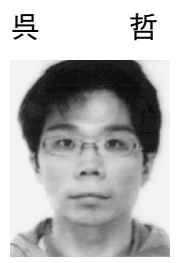

\section{英}

2014 年中央大学理工学部精密機械工学科卒業. 2014 年中央大学大学院理工学研究科博士課程前期 課程. カタツムリを規範とした全方向壁面移動ロ ボットの開発に従事.

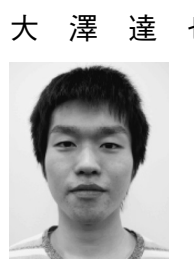

2012 年中央大学理工学部精密機械工学科卒業. 2014 年中央大学大学院理工学研究科博士課程前期 課程修了。カタッムリを規範とした全方向壁面移 動ロボットの開発に従事.

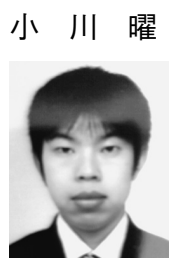

2011 年中央大学理工学部精密機械工学科卒業. 2013 年中央大学大学院理工学研究科博士課程前期 課程修了. カタツムリを規範とした全方向壁面移 動ロボットの開発に従事. CLAWAR2011, The 14th International Conference on Climbing and Walking Best technical paper Award 受賞.

\section{中 村 太 郎 (正会員)}

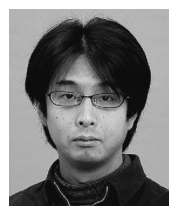

1975 年生まれ. 信州大学大学院工学系研究科博 士後期課程修了. 99 年, 秋田県立大学助手. 2004 年, 中央大学理工学部専任講師, 2006 年, 同大学 准教授をへて，2013 年より同大学教授. 現在に至 る。 2012 2013 年までスイス連邦工科大学ロー ザンヌ校 Visiting Professor. 博士 (工学). 人工 筋肉や機能性流体などのスマートアクチュエー夕 の開発と制御，および生物を規範としたバイオロ ボティクスの開発と応用に従事. 2009 年, 日本ロ ボット学会研究奨励賞, 2010 年, 日本機械学会研 究奨励賞, 2011 年, 文部科学大臣表彰若手科学者 賞などを受賞. 